\title{
Large Under-Resourced ELT Classes: What do the Learners Expect?
}

\author{
- Ramesh Prasad Ghimire
}

\begin{abstract}
This research explores the learners' expectations in a large under-resourced ELT classes in Nepalese context. The researcher used a set of questionnaire as a tool for data collection. The data were collected from a total of one hundred secondary level students at different government-aided schools in Kathmandu valley. The collected data were analyzed quantitatively and qualitatively. The overall findings of the survey revealed that the learners expect a wide variety of activities to be used in a large ELT classroom. Similarly, they highly emphasize the rapport with the teacher, and expect normal speed of speech from the teacher while teaching. The implication of these and many other findings is that large and under-resourced ELT classes in Nepalese context need special attention on the part of the teacher. As far as possible collaborative activities like group and pair works should be encouraged and the teacher must be active and dynamic in the classroom paying attention to all kinds of learners.
\end{abstract}

Key words: Large classes, group work, learner expectations, variety, diversity.

\section{Introduction}

Today, language teaching and learning activities are taking place all over the world in different educational and cultural contexts. In the context of Nepal, the teaching and learning of English varies from teaching it in a highly sophisticated and well- equipped private school settings to a very poor, crowded and under-resourced government-aided school situations. English teachers are faced with many challenges with regard to how to help learners to develop language proficiency. Our learners in a large ELT classes have many expectations, the knowledge of which can help the teachers significantly in devising appropriate methodology, selecting and developing materials and adopting a way of behaving in the classroom. Thus, the present research is focused towards this direction.

Large class generally means a class having a large number of students. In fact, it is really a complex task to define what a large class is because people have different opinions on how large number of students should be in a so called large class. About the size of a perfect class, the views differ from one person to another, one 
country to another. Regarding this, Ur (1996) states, "Large is of course a relative term, and what a large class is will vary from place to place" (p. 302). In some private language schools a group of twenty students may be considered large, in my teaching situation 4045; in some places numbers go up to the hundreds. Similarly, Hess (2006, p. 2) opines that sixty to seventy five students are not so exceptional around the world but she defines large classes as a class of thirty or more students in elementary, secondary and adult in the tertiary setting. Thus, a large class has many students and students are of different levels. There are many learner differences in the large classes such as differences on language learning ability, their cultural background, learning style, age, attitude to language, motivational orientation, etc.

Many commentators talk about large classes as a problem, and it is certainly true that they present challenges that smaller classes do not. How, for example, can we give students personal attention? How can we get students interacting with each other? What can we do to make organization smooth and effective? However, there are many benefits to teaching large classes. As Hess (2006, p.2) points out, "In large classes there are always enough students to get interaction going, and there is a rich variety of human resources".

Many large ELT classes in the Nepalese context are under-resourced, i.e. they do not have minimum facilities. They are not equipped with modern ELT technology and on line resources. Some of them do not have even a simple cassette player for listening practice. The government of Nepal supports these schools economically. But more than 97percent of the government fund is spent on the teachers' salary. The English language teachers in such situation are supported by anything except the textbook.

In a large class all students may not be similar regarding their ability or they may not be homogenous in ability. The students may be of different genders, maturity, occupations, ethnic groups, cultural and economic background, as well as personalities. There are differences among students which teacher should be fully aware of. Generally, it is believed that small classes achieve more desirable results than large ones. Studies have also brought into clearer focus of the reasons why smaller classes led to improved student outcome. Large classes are not necessarily less effective than smaller ones but they do not require more conscious effort and learning. The exact number does not really matter; what matters is how the teacher sees the class size in his/her specific situation and how effectively he/she applies the suitable methods of getting all the students to participate in the class activities uniformity.

Large classes work best when students take an active interest in the subject and when teachers personalize their presentation and respect their students. In large classes, it is difficult for the teacher to make contact with the students at the back and it is difficult for the students to ask for and receive individual attention. It may seem impossible to organize dynamic and creative teaching learning sessions. Frequently, large classes mean that it is not easy to have students walking around or changing pairs, etc. Most importantly, large classes can be quite intimidating for inexperienced teachers.

It is said that there is no right way to teach a large class. One can develop his/her own way to deal with it. But generally it is believed that teaching a small group of students is easier than 


\section{Large Under-Resourced ELT Classes: What do the Learners Expect?}

teaching a large group. But unfortunately due to budget and space constraints, many ESL (English as a second language) schools only offer large classes that may consists of 50 or more students. No matter what the size of your class is, an ESL teacher has to come up with ideas and activities that interest and engage his/her students.

Teaching in large under-resourced ELT classes is a challenging job. No matter how much we admit the advantages of teaching in large classes, the teacher faces many problems and obstacles which make it difficult to handle such class. It is difficult for both the teacher and the students. The teacher should overcome the obstacle called classroom management. The teacher should never let things in the classroom get out of control. In order to have good control he/she should take care of good organization. In this regard, Valentic $(2005$, p. 2) says, "It is very important for students to know what is expected from them". As a teacher, our aim is to reach all of our students. However, it is well known that every student has a different way of learning, and learns and progresses at different speeds. In large ELT classes there are different varieties of students. It is crystal clear that where the students are in different abilities, certainly they have their different expectations in the classroom which the teachers cannot address easily.

\section{The study}

The study aims at finding out the expectations of the learners in a large under-resourced ELT class. The population of this study was the secondary level students of government schools in Kathmandu valley. The total sample size consisted of 100 secondary level students studying in Kathmandu valley. The sample was taken from the Grade 10 of five selected secondary schools of Kathmandu valley. The selection was done through purposive nonrandom sampling procedure. I believe that this selection strategy for the respondents extends the possibility of generalization of the study. To collect primary data, one structured questionnaire was developed containing 9 closed ended questions. The respondents were requested to show their response by ticking the alternatives given. The data was analyzed both quantitatively and qualitatively.

\section{Results}

The data is presented in tables followed by discussion. Each theme of research question deserves one table and discussion as follows.

\section{Teaching learning activities}

The table 1 summarizes the responses under the theme teaching learning activities. The researcher inquired about teaching learning activities that are crucial in a large underresourced class by raising five questions. The study shows that out of the total students, 98 percent students expected varieties in teaching strategies, 2 percent of them marked undecided and none of them were in favour of one size fits all approach. The majority of students expected varieties in teaching strategies. It shows that teaching in a large under-resourced class needs to be highly diversified. So far as the teaching methods and materials are concerned, 45 percent students expected to be taught with modern teaching materials, 9 percent of them expected lecture technique, 27 percent expected explanation and illustration and 19 percent expected demonstration technique as the best technique in large mixed ability ELT classroom. The study reveals that most of the students are in favour of the use of modern technology and some of the learners love lecture technique 
though it has been criticized for its limitations. Concerning the solution of learning problems, 78 percent of the total students said that they ask the teacher when they do not find solution of some problems. Similarly, 21 percent responded that they consult other resources and only one per cent responded that they leave the problem when they did not find solution. This data shows that majority of the students expect that the teacher work as a problem solver for them. Regarding the teacher's speed of speaking in the classroom, 86 percent of the total students expected normal speed, none of them marked very slow and 14 percent expected very fast speed of speech. The obtained data indicates that majority of the students expect their teacher speak at a normal speed so that they can understand what the teacher is saying.

Table 1: Teaching Learning Activities

\begin{tabular}{|l|l|c|}
\hline \multicolumn{1}{|c|}{ Questions } & \multicolumn{1}{c|}{ Options } & \multicolumn{1}{c|}{$\begin{array}{c}\text { Responses } \\
\text { (in percentage) }\end{array}$} \\
\hline \multirow{2}{*}{$\begin{array}{l}\text { 1. Do you like your teacher } \\
\text { bringing variety in his } \\
\text { teaching strategies? }\end{array}$} & a. Yes & 98 \\
\cline { 2 - 3 } & b. No & 0 \\
\cline { 2 - 3 } & c. Undecided & 2 \\
\hline \multirow{4}{*}{ 2. You like to be taught with: } & a. Modern teaching materials & 45 \\
\cline { 2 - 3 } & b. Teacher's voice only (lecture) & 9 \\
\cline { 2 - 3 } & c. Explanation and illustration & 27 \\
\cline { 2 - 3 } & d. Demonstration & 19 \\
\hline \multirow{2}{*}{$\begin{array}{l}\text { 4. What do you do if you don't } \\
\text { find the answer of some } \\
\text { problems? }\end{array}$} & a. I ask the teacher. & 21 \\
\cline { 2 - 3 } & b. I consult other resources. & 1 \\
\cline { 2 - 3 } & c. I leave it. & 14 \\
\hline $\begin{array}{l}\text { 5. What do you expect from } \\
\text { your teacher regarding the } \\
\text { speed of speech? }\end{array}$ & a. Very fast & 86 \\
\cline { 2 - 3 } & b. Normal & 0 \\
\cline { 2 - 3 } & c. Very slow & 21 \\
\hline
\end{tabular}

\section{The teacher and learner roles}

I have summarized the responses concerning the role of the teacher and the learners in a large ELT class in the table 2 . The study confirms that 71 percent of the total students expected working in a group, 23 percent students expected working in a pair, and only 6 percent expected to work alone in the ELT classroom. This data indicates that majority of the students enjoy working in a group. Concerning the rapport between the teacher and the students, 92 percent of the total students liked their teachers to be close with them,
3 percent marked undecided and 5 percent of them did not like their teachers to be close with them. As a whole the majority of the students expected the close relationship with the teacher. To find out the expectations of students regarding the position of teacher in the classroom, the students were asked to show their responses whether they expect their teacher moving all around the class or standing at the front. The result shows that 95 percent students expected their teacher move in different places in the classroom and only 5 percent expected their teacher stand at the front. 
As a whole it was found that majority of the students want their teacher to move all around the classroom while $\mathrm{s} / \mathrm{he}$ is teaching. One question was intended to find out the focus of the teacher on different kinds of students. The data shows that only 2 percent of the total students opined that they like their teacher focusing more on the intelligent students in the classroom. But a vast majority of them, i.e. 98 percent did not like this, and none of the students marked undecided. These data indicate that teacher should not focus only on the intelligent students in the classroom.

Table 2: The teacher and Learner Roles

\begin{tabular}{|l|l|c|}
\hline \multicolumn{1}{|c|}{ Questions } & \multicolumn{1}{|c|}{ Options } & Responses \\
\hline \multirow{3}{*}{ 5. I enjoy working: } & a. in a group & 71 \\
\cline { 2 - 3 } & b. in a pair & 23 \\
\cline { 2 - 3 } & c. alone & 6 \\
\hline \multirow{3}{*}{ 6. Do you like your teacher to be close to you? } & a. Yes & 92 \\
\cline { 2 - 3 } & b. No & 3 \\
\cline { 2 - 3 } & c. Undecided & 5 \\
\hline \multirow{2}{*}{ 7. I expect my teacher: } & a. moving in the class & 95 \\
\cline { 2 - 3 } & b. standing at the front & 5 \\
\hline \multirow{2}{*}{$\begin{array}{l}\text { 8. Do you like your teacher focusing more the } \\
\text { intelligent students only in the classroom }\end{array}$} & a. Yes & 98 \\
\cline { 2 - 3 } & b. No & 0 \\
\cline { 2 - 3 } & c. Undecided & 2 \\
\hline
\end{tabular}

\section{Discussion}

The result of the present study on the learners' expectations in a large under-resourced ELT classes bears many similarities to Khati's study in Ramechhap. Both of these studies show that large ELT classes require a different technique to be implemented. Most of the students expect varieties in teaching strategies to make teaching learning effective and enjoyable. The study shows that the same learning tasks and activities are not appropriate for all the students. Therefore, the teacher should devise different levels of activities according to their abilities. Similarly, a majority of the students expect to be taught using the modern teaching materials in a large under-resourced ELT classroom. The main purpose of teaching is to enable the students to learn the things. So, while teaching teacher's speed of speech should be slow, i.e. normal. The study reveals that a teacher cannot give individual attention in a large ELT class. Therefore, time duration should be increased to enhance teaching learning process. The good relationship between students and teachers develop the teaching learning process. Therefore, students' and teachers' relationship should be remarkable. Since mixed ability in large classes is a natural phenomenon, teacher should not focus only the intelligent students neglecting the poor students. Moreover, he/she should behave all the students equally in the classroom. Collaborative activities are very helpful in large under-resourced ELT classroom. Therefore, collaborative activities such as group work, pair work, jigsaw activities, collaborative community projects and collaborative writing need to be 
focused in a large under-resourced ELT classroom.

\section{Conclusion}

The study reveals many facts about what the students expect in a large under-resourced ELT classroom and what the teachers need to do in order to address those expectations. The research shows that the learners enjoy variety in teaching, and expect their teacher bring this feature in the classroom. Most of the students expect the use of modern technology in teaching, and some of them love lecture technique though it has been criticized for its limitations. Likewise, a very few students like to solve their problems themselves by consulting materials and resources. Instead, a vast majority of them expect that the teacher work as a problem solver for them. A great majority of the students expect that their teacher speak at a normal speed in the classroom. Since most of the of the students in a large classroom enjoy working in groups, group and pair works need to be encouraged. The rapport between the teacher and students is highly expected by many students, so the teacher must be aware of establishing a good relation with the students. As a teacher, one should be dynamic in the classroom paying attention to all kinds of students. He/she should not focus only on the front benchers

\section{About the author}

Mr. Ghimire is a Technical Officer at Educational Training Center, Surkhet. A life member of NELT (Nepal English Teachers Association), Mr. Ghimire is also the editor of the academic journal The Profession. His area of interest includes classroom diversity, English grammar, teacher education and critical pedagogy.

\section{References}

Bartels-Ellis, F. (2009). Equal opportunity and diversity in ELT. Retrieved on May 17, 2012, from http://www.learningenglish. org.UK/2009/eod_docs/ FIONA\%2013 ART.

Copur, D. S. (2005). Coping with the problems of mixed ability classes. Retrieved on May 17, 2012 from htt://iteslj.org/ techniques/sali-copur-mixedablity.html/

Dewan, S. (2003). Teaching large multilevel classes. Journal of NELTA, Vol. 8: 158-162.

Ghimire, R. (2010). Managing multilevel diversity in ELT classes. An Unpublished M.Ed. Thesis, Tribhuvan University, Kathamndu. Harmer, J. (2008). The practice of English language teaching. London: Longman.

Hess, N. (2006). Teaching large multilevel classes. Cambridge: Cambridge University Press.

Jahn, A. (2008). Promoting collaboration in mixed ability EFL classroom at tertiary level in Bangladesh. Journal of NELTA, Vol. 13: 49-56.

Kerry, T. (1981). Teaching bright pupils in mixed ability classes. London: Macmillan.

Khan, H. R. (2005). CLT in large class: conforming and contrast. Journal of NELTA, Vol. 12: 57-64.

Khati, A. R. (2010). Teaching English in large multilevel classroom. Retrieved on May 19, 2011 from http://www.teachingenglish. org.UK/forum-topic/teaching-englishmultilevelmulti-lingual-classroom.

Prodromou, L. (1992). Mixed ability classes. London: Macmillan.

Ur, P. (1996). A course of language teaching. Cambridge: Cambridge University Press.

Valentic, D. (2005). ELT in multilevel classes. Retrieved on May 19, 2011 from http:// associates.iastef/org/pages/materials/pdf.doc 